\title{
Pengembangan Bahan Ajar Tematik Berbasis Proyek untuk Mengembangkan Keterampilan Berpikir Kreatif dan Karakter Wirausaha Peserta Didik Tunanetra
}

\author{
Siti Fatimah ${ }^{1}$, Budiono $^{2}$ \\ Institut Agama Islam NU Kebumen ${ }^{1}$, SLB Putra Manunggal Gombong ${ }^{2}$ \\ $\underline{\text { stfatimah89@gmail.com }}$
}

\begin{abstract}
This study aims to develop project-based thematic teaching materials to improve creative thinking skills and entrepreneurial skill of blind students. The design of teaching material development uses the Design Based Research (DBR) approach. The DBR stage of four stages, namely the needs analysis, product design/development, product testing, and reflection. The subjects in this study were 2 blind students at SLB Putra Manunggal Gombong, Kebumen. The instruments used were questionnaire, interview, observation, and test. The data analysis technique uses qualitative descriptive. The results of the study indicate: 1) Project-based thematic teaching materials are suitable for blind students; 2) Project learning using thematic teaching materials effectively improves creative thinking skills and entrepreneurial skill of blind students; 3) The develop in entrepreneurial character of blind students shows a high category with the percentage of $84 \%$, while the increase in students' creative thinking skills shows a moderate category with an N-Gain value of 0.60 .
\end{abstract}

Keywords: Project-Based Thematic Teaching Materials, Creative Thinking Skills, Entrepreneurial Skill

\begin{abstract}
Abstrak
Penelitian ini bertujuan untuk mengembangkan bahan ajar tematik berbasis proyek untuk meningkatkan keterampilan berpikir kreatif dan karakter wirausaha peserta didik tunanetra. Desain pengembangan bahan ajar menggunakan pendekatan Design Based Research (DBR). Tahapan DBR yang digunakan terdiri dari empat tahap, yaitu tahap analisis kebutuhan, tahap desain/ pengembangan produk, tahap pengujian produk, dan tahap refleksi. Subjek dalam penelitian ini adalah 2 peserta didik tunanetra di SLB Putra
\end{abstract}


Manunggal Gombong, Kebumen. Instrumen yang digunakan adalah lembar angket, lembar wawancara, lembar observasi, dan lembar tes. Teknik analisis data menggunakan deskriptif kualitatif. Hasil penelitian menunjukkan: 1) Bahan ajar tematik berbasis proyek layak digunakan bagi peserta didik tunanetra; 2) Pembelajaran proyek menggunakan bahan ajar tematik efektif meningkatkan keterampilan berpikir kreatif dan karakter wirausaha peserta didik tunanetra; 3) Besar pengembangan karakter wirausaha peserta didik tunanetra menunjukkan kategori tinggi/baik yaitu dengan persentase sebesar $84 \%$, sedangkan peningkatan keterampilan berpikir kreatif peserta didik menunjukkan kategori sedang dengan nilai $\mathrm{N}$-Gain 0,60 .

Kata Kunci: Bahan Ajar Tematik Berbasis Proyek, Keterampilan Berpikir Kreatif, Karakter Wirausaha,

\section{PENDAHULUAN}

Pendidikan adalah usaha sadar dan terencana untuk mewujudkan suasana belajar dan proses pembelajaran agar peserta didik secara aktif mengembangkan potensi dirinya untuk memiliki kekuatan spiritual keagamaan, pengendalian diri, kepribadian, kecerdasan, akhlak mulia, serta keterampilan yang diperlukan dirinya, masyarakat, bangsa dan negara (UU Sisdiknas pasal 1 ayat 1). Dalam upaya pengembangan potensi peserta didik, pendidik diharapkan tidak hanya menekankan pada aspek kognitif, namun pengembangan aspek afektif dan psikomotorik perlu ditekankan selama pembelajaran berlangsung. Oleh sebab itu, seorang pendidik harus memiliki inovasi agar pembelajaran menjadi lebih menyenangkan dan bermakna bagi peserta didik. Inovasi-inovasi pembelajaran yang dapat dilakukan oleh pendidik antara lain penggunaan strategi dan media pembelajaran yang bervariasi.

Berdasarkan hasil observasi di SLB Putra Manunggal Gombong, peserta didik tunanetra selama ini cenderung menggunakan metode ceramah dan memiliki keterbatasan media pembelajaran baik dalam bentuk cetak dan non cetak. Dampak dari penggunaan metode ceramah dan keterbatasan media menyebabkan pembelajaran menjadi membosankan dan kurang adanya pengembangan keterampilan baik pada aspek afektif dan psikomotorik. Muhammad mengemukakan pembelajaran menggunakan ceramah tidak dapat menumbuhkan proses partisipasi aktif peserta didik, berkurangnya motivasi belajar, dan rendahnya hasil belajar yang diperoleh peserta didik. ${ }^{1}$ Selanjutnya, Suhendro menyebutkan pembelajaran menggunakan metode ceramah memberikan dampak yang kurang baik terhadap hasil belajar peserta didik, cenderung membosankan, dan kurang memberikan kesempatan kepada peserta

\footnotetext{
${ }^{1}$ Muhammad, "Pengaruh Metode Pembelajaran Kooperatif Tipe Jigsaw Terhadap Motivasi Dan Hasil Belajar Mahasiswa.," Jurnal Keperawatan 9, no. No 1 (2018): 65-71.
} 
didik untuk terlibat aktif selama pembelajaran ${ }^{2}$. Selain hanya menyampaikan materi secara lisan, penggunaan metode ceramah juga sangat sedikit dalam memanfaatkan media pembelajaran. ${ }^{3}$

Media pembelajaran seperti alat peraga, bahan ajar, dan video serta simulasi memiliki peran yang besar terhadap keberhasilan pembelajaran. Selain itu, media pembelajaran mampu menciptakan pembelajaran menjadi menyenangkan dan real. Penggunaan media dalam bentuk bahan ajar braille bagi peserta didik tunanetra menjadi salah satu media yang dapat digunakan dalam pembelajaran. ${ }^{4}$ mengemukakan bahwa bahan ajar merupakan salah satu sumber belajar yang sangat penting dalam pembelajaran, khususnya untuk peserta didik tunanetra. Triyanto \& Rudiyati menyebutkan bahwa bahan ajar dapat mempermudah aktivitas belajar peserta didik tunanetra. ${ }^{5}$ Utomo menerangkan bahwa melalui bahan ajar braille, peserta didik dapat memahami materi dengan mudah dan mampu menumbuhkan kepercayaan diri sehingga berdampak pada peningkatan hasil belajar peserta didik tunanetra. Bahan ajar yang baik adalah bahan ajar yang disesuaikan dengan kebutuhan peserta didik dan kurikulum yang berlaku di sekolah. ${ }^{6}$

Di daerah Kebumen, Jawa Tengah merupakan salah satu penghasil biji jenitri yang sedang mengalami kemajuan pesat. Biji Jenitri asal Kebumen sangat diminati oleh pembeli dari Cina dan India. Berdasarkan Biro Pusat Statistik (BPS), data ekspor biji jenitri tiap tahun mengalami peningkatan. Periode 2017 nilai ekspor produk biji jenitri berada di level 10,10 USD yang berarti terjadi peningkatan sebesar $200 \%$. Sedangkan negara-negara yang menjadi pasar tujuan ekspor terbesar bagi komoditi ini adalah Jepang, Thailand, Singapura, China, Malaysia, Italia, Jerman, Taiwan, Amerika Serikat, dan Republika Korea. Sedangkan negaranegara yang menjadi pasar terbesar bagi produk ini adalah Yunani, Inggris, Perancis, Spanyol, Singapura, Kanada, Siprus, Denmark, Fiji, dan Chili. Sedangkan India merupakan negara yang memiliki permintaan cukup besar pada biji jenitri ini. Mengingat mayoritas penduduk India beragam Hindu, maka produk hasil alam ini dibuat menjadi salah satu perangkat ibadah yang disebut dengan mala japa atau tasbih. Selain kegunaan sebagai alat ibadah, masyarakat India

\footnotetext{
${ }^{2}$ Suhendro, Pengaruh Metode Demonstrasi Dan Metode Ceramah Terhadap Hasil Belajar Geografi Di SMAN 3 Metro (Unila: FKIP, 2018).

3 Suhendro.

${ }^{4}$ Amin, "Analisis Bahan Ajar Modul Statistika Pada Program Studi Pendidkan Matematika IKIP PGRI Bojonegoro," Jurnal Edutama 3, no. No 2 (2016): 1-8.

${ }^{5}$ Triyanto \& Rudiyati, “Pengembangan Modul Pembelajaran Aksara Jawa 'Dinta Swara' Dalam Huruf Braille Untuk Siswa Tunanetra," Jurnal Pembanguna Pendidikan: Fondasi Dan Aplikasi 5, no. No 2 (2017): 176-86.

${ }^{6}$ Utomo, "Pengembangan Modul Braille Pembelajaran Orientasi Dan Mobilitas Tingkat Lanjut Untuk Siswa Tunanetra Di SMPLB - A YPAB Surabaya," Tugas Akhir: Program Pascasarjana UM., 2018.
} 
meyakini bahwa biji Jenitri memiliki khasiat untuk menyembuhkan berbagai macam penyakit. Selain India, di indonesia yang mayoritas menganut agama Islam juga telah banyak menggunakan biji Jenitri sebagai tasbih. Seiring dengan perkembangan zaman, biji jenitri telah digunakan sebagai peralatan ibadah dan pendukung kesehatan, namun dikemas dengan lebih menarik sesuai dengan tren desain di pasar dunia. Biji jenitri diolah menjadi produk perhiasan antara lain berupa cincin dan gelang. ${ }^{7}$ Merujuk pada pesatnya perkembangan biji Jenitri di daerah Kebumen, bahan ajar yang mengembangkan potensi lokal sangat dibutuhkan. Bahan ajar ajar berbasis potensi lokal akan lebih maksimal jika disertai metode dalam pembelajaran.

Salah satu metode pembelajaran yang inovatif dan menyenangkan adalah metode proyek. Melalui pembelajaran berbasis proyek, keterampilan berpikir peserta didik akan terasah dan meningkat. Sari, dkk menghasilkan temuan bahwa pembelajaran berbasis proyek (Project Based Learning/PjBL) mempengaruhi tingkat kreativitas sisw. ${ }^{8}$ Upaya dalam mengembangkan kemampuan berpikir kreatif mahasiswa adalah dengan memberikan kebebasan dalam mendesain proyek yang diawali dengan permasalahan dalam dunia nyata. Hal ini sesuai dengan karakteristik PjBL bahwa prinsip pembelajaran proyek adalah memberikan permasalahan dunia nyata untuk dijadikan obyek investigasi sehingga membantu siswa mengembangkan kemampuan berpikir, keterampilan memecahkan masalah, dan keterampilan intelektual yang nantinya memberikan kesempatan kepada siswa untuk berpikir dan mencipta.

Berdasarkan penjelasan di atas, tujuan dalam penelitian ini adalah mengembangkan bahan ajar tematik "Jenitri” berbasis proyek untuk meningkatkan keterampilan berpikir kreatif dan karakter wirausaha peserta didik tunanetra.

\section{METODOLOGI PENELITIAN}

\section{Jenis Penelitian}

Penelitian ini menggunakan pendekatan Design Based Research (DBR) yang dikembangkan oleh Reeves. Tahapan DBR yang digunakan terdiri dari empat tahap, yaitu tahap analisis masalah/analisis kebutuhan, tahap desain/tahap pengembangan produk, tahap pengujian produk, dan tahap refleksi/tahap evaluasi.

\section{Waktu dan Tempat Penelitian}

Penelitian ini dilakukan pada semester gasal tahun 2018 di SLB Putra Manunggal Gombong, Kebumen.

\footnotetext{
${ }^{7}$ Warta Ekspor, Pengembangan Desain Perhiasan Jenitri (Kementerian Perdagangan RI, 2017).

${ }^{8}$ Sari, "Pengaruh Pembelajaran Berbasis Proyek Terhadap Kreativitas Siswa Melalui Elektroskop Sederhana," in . . Prosiding Seminar Nasional Fisika (E-Journal) UNJ. Vol IV, 2015, 19-24.
} 


\section{Subjek Penelitian}

Subjek dalam penelitian ini adalah 2 peserta didik SMA tunanetra di SLB Putra Manunggal Gombong, Kebumen.

\section{Prosedur}

Prosedur dalam penelitian ini dapat dilihat pada gambar 1 dan 2.



Gambar 1. Alur Pendekatan DBR

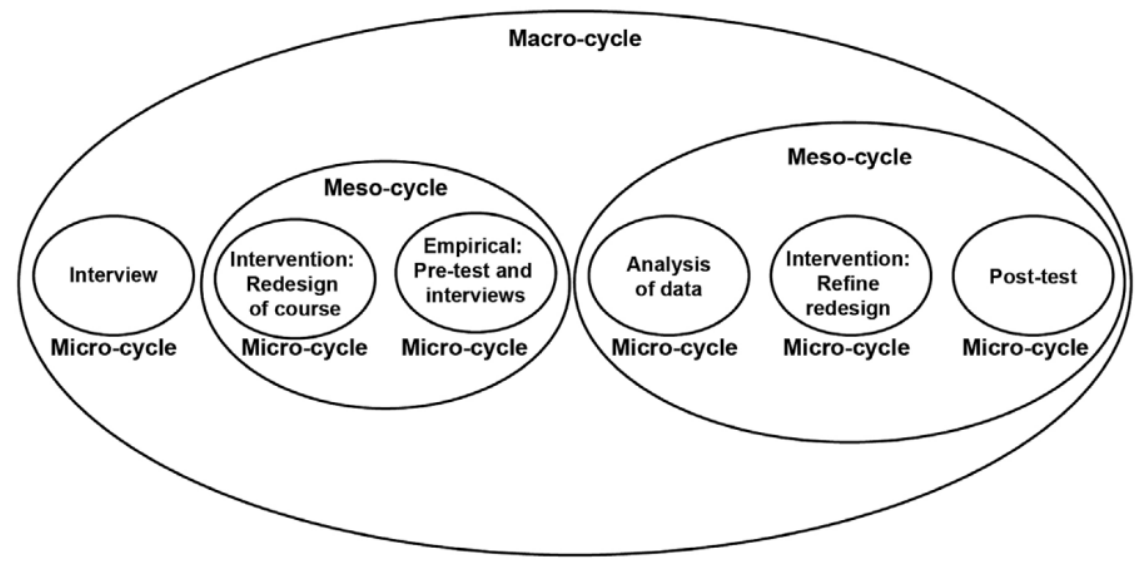

Gambar 2. Konsep Alur Siklus pada Pendekatan DBR

\section{Data, Instrumen, dan Teknik Pengumpulan Data}

Instrumen yang digunakan adalah lembar angket, lembar wawancara, lembar observasi, dan lembar pretest dan posttest. Lembar angket yang terdiri dari skala likert dengan empat skala digunakan untuk mengukur kelayakan bahan ajar yang dikembangkan. Validitas dan penilaian kelayakan bahan ajar dilakukan oleh empat ahli, yaitu ahli materi, ahli bahasa, ahli media, dan seorang guru di SLB.

\section{Teknik Analisis Data}

Teknik analisis data dilakukan dengan menggunakan metode deskriptif kualitatif. Untuk mengetahui kelayakan bahan ajar yang dikembangkan, menggunakan tabel kategori seperti pada tabel 1 .

Tabel 1. Kategori Kelayakan Bahan Ajar 


\begin{tabular}{cc}
\hline $\begin{array}{c}\text { Rerata } \\
\text { Skor }(\overline{\boldsymbol{X}})\end{array}$ & Kategori \\
$>3,25$ & Sangat Baik (SB)/Sangat Setuju \\
$-4,00$ & $(\mathrm{SS})$ \\
$>2,50$ & Baik (B)/Setuju (S) \\
$-3,25$ & Tidak Baik (TB)/Tidak Setuju \\
$>1,75$ & $(\mathrm{TS})$ \\
$-2,50$ & Sangat Tidak Baik \\
$1,00-$ & $(\mathrm{STB}) /$ Sangat Tidak Setuju (STS) \\
\hline
\end{tabular}

(Sumber: Diadaptasi dari Widoyoko, 2012)

Data keefektifan diperoleh dari data pretest dan postest peserta didik. Untuk mengolah data kefektifan menggunakan persamaan 1 (Arikunto, 2006).

$$
\left.\bar{X}=\frac{\sum x}{\sum N} \quad \text { (Pers. } 1\right)
$$

Berdasarkan pengolahan data keefektifan selanjutnya diinterpretasikan tingkat keefektifannya. Bahan ajar dikatakan efektif jika rata-rata keterampilan berpikir kreatif peserta didik mencapai $\geq 70$. Jika kurang dari 70, maka baha ajar dikatakan tidak efektif. Artinya, jika rata-rata nilai keterampilan berpikir kreatif peserta didik mencapai $\geq 70$, bahan ajar yang dikembangkan dapat dikatakan memiliki peran yang efektif dalam meningkatkan keterampilan berpikir kreatif peserta didik dan dapat diimplementasikan. Kriteria keefektifan yang digunakan sebagai pedoman dapat dilihat pada tabel 2.

Tabel 2. Kriteria Kefektifan Pengembangan Bahan Ajar

\begin{tabular}{cc}
\hline $\begin{array}{c}\text { Skor } \\
\text { Keefektifan }\end{array}$ & Kriteria \\
\hline $85-$ & $\begin{array}{c}\text { Sangat } \\
\text { efektif, tidak } \\
\text { perlu revisi } \\
\text { Efektif, } \\
\text { tidak perlu } \\
\text { revisi }\end{array}$ \\
$50-64$ & $\begin{array}{l}\text { Kurang } \\
\text { efektif, perlu } \\
\text { revisi Tidak }\end{array}$ \\
$0-49$ & $\begin{array}{l}\text { Tefektif, revisi } \\
\text { total }\end{array}$ \\
\hline (Sumber: Yamasari, 2010)
\end{tabular}

Selanjutnya, untuk menganalisis penilaian karakter jiwa wirausaha peserta didik menggunakan persentase yaitu seperti pada persamaan 2 .

Persentase jiwa wirausaha $(p)=\frac{\text { skor hasil penelitian }}{\text { skor tertinggi }} \times 100 \% \quad$ (Pers. 2) 
Setelah dianalisis tingkat persentase, angka persentase diinterpretasikan dalam bentuk klasifikasi seperti pada tabel 3.

Tabel 3. Tabel Kriteria Karakter Jiwa Wirausaha

\begin{tabular}{cc}
\hline $\begin{array}{c}\text { Skor } \\
\text { Karakter } \\
\text { Jiwa } \\
\text { Wirausaha } \\
(\boldsymbol{\%})\end{array}$ & Kriteria \\
\hline $86-100$ & Sangat \\
$70-85$ & Baik \\
$60-69$ & Baik \\
& Kurang \\
$0-59$ & Baik \\
& Tidak \\
Baik
\end{tabular}

(Diadaptasi dari Widoyoko, 2012)

Besar peningkatan keterampilan berpikir kreatif dan karakter wirausaha menggunakan $N$-Gain seperti pada persamaan 3 (Meltzer, 2002).

$N-$ gain $=\frac{\text { posttest score }- \text { pretest score }}{\text { maximum possible score }- \text { pretes score }}$

(Pers. 3)

Tabel 4. Klasifikasi N-Gain

\begin{tabular}{cc}
\hline $\begin{array}{c}\text { Rata- } \\
\text { rata } N-\end{array}$ & Klasifikasi \\
Gain & \\
$0,70<$ & Tinggi \\
$N$-Gain $\leq$ & \\
1,00 & \\
$0,30<$ & Sedang \\
$N-$-Gain $\leq$ & \\
0,70 & \\
$N-$ & Rendah \\
Gain $\leq 0,30$ & \\
\hline
\end{tabular}

(Sumber: Hake, 2007)

\section{HASIL DAN PEMBAHASAN}

Pengembangan bahan ajar tematik menggunakan tipe keterpaduan Webbed yaitu mengambil tema "Jenitri" untuk peserta didik tunanetra disesuaikan dengan analisis kebutuhan peserta didik di SLB Putra Manunggal Gombong, Kebumen dan melihat potensi lokal daerah Kebumen yang saat ini sedang berkembangan dengan pesat (tahap Micro-Cycle 1/ analysis 
and exploration). Perpaduan materi di bahan ajar ini terdiri dari materi Biologi, Geografi, Prakarya dan Kewirausahaan, dan Pendidikan Agama Islam (PAI). Diagram pemetaan Kompetensi Dasar tipe Webbed pada tema Jenitri dapat dilihat pada gambar 3.

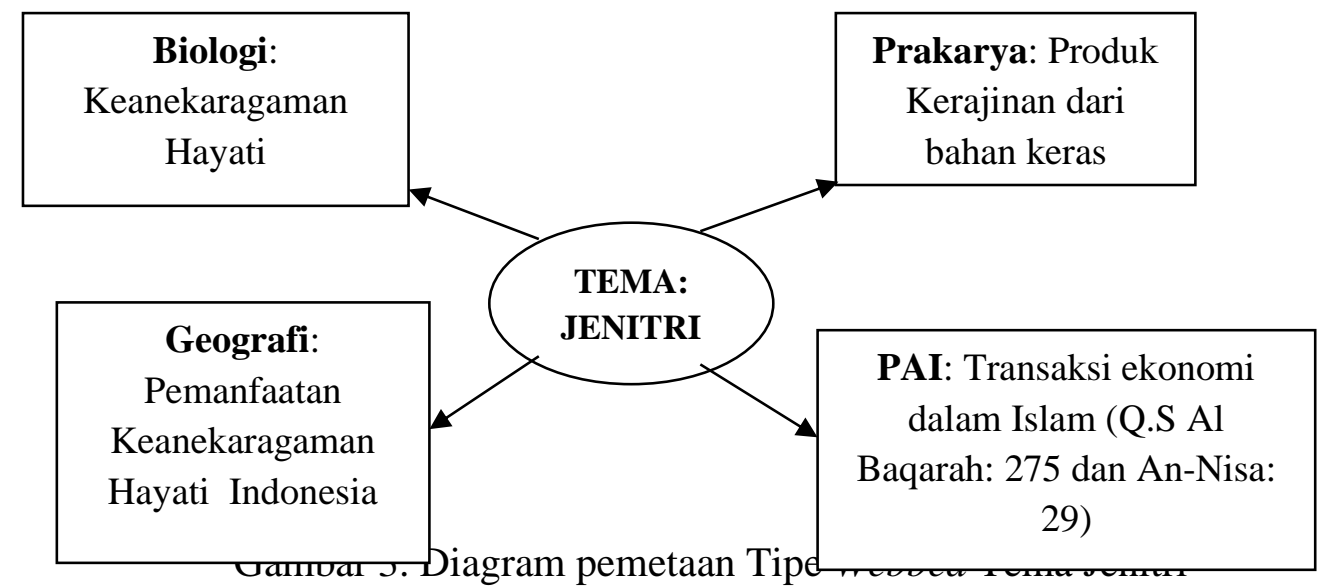

Selain menggunakan tema, pengembangan bahan ajar juga memperhatikan aspek-aspek metode proyek pada pengemasan materi. Beberapa aspek metode proyek yang terdapat dalam bahan ajar adalah dengan mengacu pada langkah-langkah metode proyek. Langkah-langkah dalam metode proyek adalah: (1) Starts With the Essential Question, (2) Design a Plan for the Project, (3) Creates a Schedule, (4) Monitor the Students and the Progress of the Project, (5) Assess the Outcome, (6) Evaluate the Experiences.

Langkah pertama pada metode proyek adalah mengawali materi dengan memberikan pertanyaan yang esensial seperti "pernahkah kalian memegang biji jenitri?" atau "pernahkah kalian membeli benda-benda seperti gelang atau tasbih yang terbuat dari biji jenitri? ’. Setelah peserta didik mendapatkan pertanyaan tersebut, peserta didik diminta untuk diskusi dan menuliskan hasilnya.

Jika sudah pernah memegang biji buah jenitri, coba kalian jelaskan ciri-ciri dari buah jenitri tersebut berdasarkan perabaan kalian? Diskusikan dengan teman kalian untuk menjawabnya dan tuliskan di kolom yang tersedia!

Ciri-Ciri Jenitri

Gambar 4. Contoh kolom hasil diskusi di bahan ajar 
Setelah diawali dengan pertanyaan-pertanyaan dan diskusi, peserta didik diarahkan untuk membuat produk dari biji jenitri. Peserta didik diberikan kebebasan dalam membuat produk.

Tugas Mandiri: Setelah kalian membaca berbagai macam manfaat dari Jenitri, Buatlah beberapa benda yang dapat dibuat dengan menggunakan Jenitri. Sebagai contoh membuat tasbih, kalung, gelang, dan gantungan kunci sesuai dengan kreativitas kalian! Setelah selesai membuat hasil karya, silahkan kalian tawarkan kepada calon pembeli dengan harga minimal Rp 5.000,00!

Gambar 5. Contoh kolom Pembuatan Proyek

Gambar 5 menjelaskan bahwa pendidik tidak membatasi kreativitas peserta didik dalam membuat sebuah produk yang akan dibuat. Hal ini bertujuan untuk mengasah keterampilan serta melatih jiwa wirausaha peserta didik dengan memberikan kesempatan kepada peserta didik untuk menjual hasil produk yang telah dibuat. Bahan ajar tematik yang telah dikembangkan disusun dengan menggunakan huruf Braille agar memudahkan peserta didik tunanetra dalam memahami materi yang disajikan.



Gambar 6. Huruf dan Angka Braille

Setelah bahan ajar disusun secara lengkap, langkah selanjutnya adalah validasi. Validitas dilakukan dengan menggunakan penilaian 1 ahli materi, 1 ahli media, 1 ahli bahasa, dan 1 pendidik SLB Putra Manunggal Kebumen seperti yang terlihat pada tabel 4 (tahap MicroCycle 2/ analysis and exploration).

Tabel 4. Ringkasan Hasil Kelayakan Bahan Ajar

\begin{tabular}{ccc}
\hline Aspek & $\begin{array}{c}\text { Rerata } \\
\text { Skor }\end{array}$ & Kriteria \\
\hline Materi & 3,25 & Baik \\
Bahasa & 3,45 & $\begin{array}{c}\text { Sangat } \\
\text { Baik } \\
\text { Sangat } \\
\text { Baik }\end{array}$ \\
Media & 3,50 & $\begin{array}{c}\text { Sangat } \\
\text { Baik }\end{array}$ \\
\hline Rerata & $\mathbf{3 , 4 0}$ & \\
\hline
\end{tabular}


Berdasarkan tabel 4, dapat diketahui bahwa hasil kelayakan tiap aspek bahan ajar menunjukkan Sangat Baik dengan rerata skor 3,40. Artinya, bahan ajar yang telah disusun dapat digunakan ke tahap selanjutnya, yaitu tahap uji coba ke lapangan (tahap Micro-Cycle 3/ evaluation and reflection).

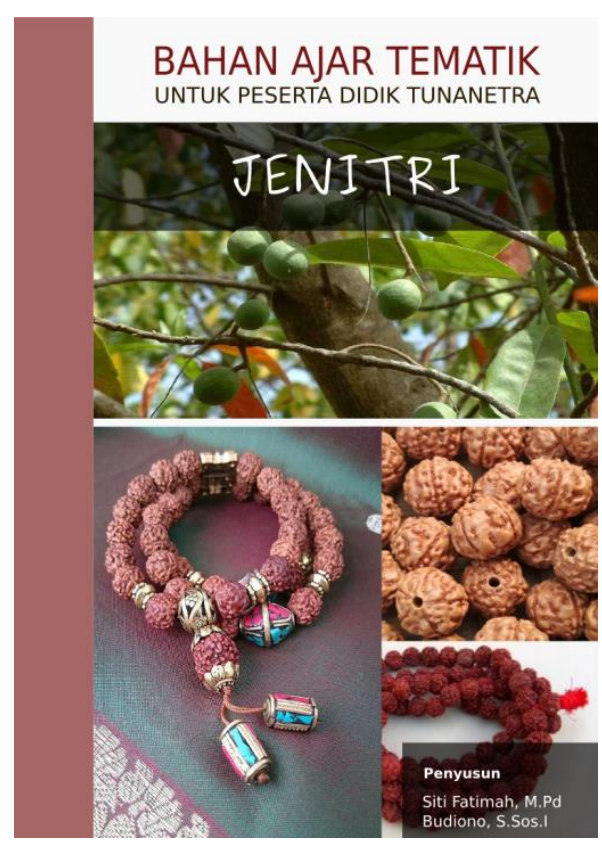

Gambar 7. Cover Bahan Ajar

Pada tahap Micro-cycle 3 dilakukan pretest kepada peserta didik untuk mengetahui kemampuan awal keterampilan berpikir kreatif dan jiwa wirausaha peserta didik. Hasil nilai pretest dan hasil observasi dapat dilihat pada tabel 5.

Tabel 5. Hasil Pretest Keterampilan Berpikir Kreatif dan hasil observasi karakter wirausaha

\begin{tabular}{ccc}
\hline Responden & $\begin{array}{c}\text { Nilai } \\
\text { Pretest }\end{array}$ & $\begin{array}{c}\text { Skor } \\
\text { Karakter } \\
\text { Wirausaha } \\
(\mathbf{\%})\end{array}$ \\
\hline 1 & 40 & 15 \\
2 & 55 & 28 \\
\hline Rata-Rata & $\mathbf{4 7 , 5}$ & $\mathbf{2 1 , 5}$ \\
\hline
\end{tabular}

Tabel 5 menunjukkan nilai rata-rata keterampilan berpikir kreatif dan karakter jiwa wirausaha peserta didik masih rendah yaitu 47,5 dan 21,5\%. Selanjutnya, pada tahap ini diakhir 
pembelajaran pada siklus I peserta didik diminta untuk memberikan respon pada bahan ajar yang telah digunakan seperti yang terlihat pada tabel 6 .

Tabel 6. Hasil wawancara Peserta Didik pada Siklus I (Micro-cycle 3)

\begin{tabular}{lccc}
\hline Aspek & $\begin{array}{c}\text { Jumla } \\
\text { h item }\end{array}$ & $\begin{array}{c}\text { Rerat } \\
\text { a Skor }\end{array}$ & $\begin{array}{c}\text { Kriteri } \\
\text { a }\end{array}$ \\
\hline $\begin{array}{c}\text { Kemudaha } \\
\text { Pemahaman } \\
\text { Konsep } \\
\text { Minat } \\
\text { terhadap Bahan } \\
\text { Ajar } \quad 3\end{array}$ & 2,80 & Setuju \\
$\begin{array}{c}\text { Penggunaa } \\
\text { n Bahan Ajar } \\
\text { Penyajian }\end{array}$ & 2 & 3,30 & $\begin{array}{c}\text { Sangat } \\
\text { Setuju }\end{array}$ \\
Bahan Ajar & 3 & 3,00 & Setuju \\
$\quad$ Rerata Skor & 5 & 2,75 & Setuju \\
\hline
\end{tabular}

Berdasarkan tabel 6 dapat diketahui bahwa rerata skor respon peserta didik pada siklus I menunjukkan kategori Setuju/Baik. Hal ini menunjukkan bahwa peserta didik antusias dalam menggunakan bahan ajar selama pembelajaran. Saran yang diberikan peserta didik pada tahap ini adalah penulisan ayat Al-qur'an (Q.S. Al Baqarah: 275 dan An-Nisa: 29) tentang hukum jual beli secara Islam masih belum begitu jelas sehingga perlu diperbaiki penulisan Braillenya. Saran yang diberikan dari peserta didik sebagai acuan untuk menuju ke siklus II. Berikut adalah penjelasan uji coba pada siklus II (Meso-Cycle II).

\section{Micro-cycle 4 (analysis and exploration)}

Pada tahap ini, hasil data yang diperoleh dari siklus I dianalisis untuk menghasilkan produk bahan ajar yang layak. Saran yang diberikan dari peserta didik dijadikan sebagai dasar untuk merevisi.

\section{Micro-cycle 5 (design and construction)}

Tahap ini adalah tahap proses perbaikan konten bahan ajar sesuai dengan saran yang telah diberikan. Saran yang diberikan peserta didik seperti memperbaiki tulisan Alquran Braille tentang hukum jual beli Islam dilakukan dengan cara menulis ulang. Berdasarkan hasil wawancara dengan peserta didik, bahan ajar yang telah dikembangkan cukup membuat peserta didik semangat dan antusias dalam memahami materi. Karena selama ini belum pernah ada 
bahan ajar tematik yang digunakan selama pembelajaran. Selain itu, keterpaduan materi menjadi hal baru yang baru bagi peserta didik.

Pembuatan sebuah karya/proyek selama pembelajaran juga menjadi hal yang menantang dan menyenangkan. Suparno menjelaskan bahwa salah satu karakteristik/sifat dari proyek adalah tema harus menantang dan umumnya membuat sesuatu/produk yang belum biasa dilakukan. ${ }^{9}$ Oleh sebab itu, sebuah proyek pada umumnya menggunakan tema/permasalahan yang belum biasa dilakukan sehingga membuat peserta didik tertantang untuk menyelesaikan proyek. Hal ini sejalan dengan penelitian Chiang \& Lee yang menyebutkan bahwa hal yang sangat penting pada pembelajaran berbasis proyek adalah pemecahan masalah. ${ }^{10}$ Untuk menyelesaikan sebuah proyek, peserta didik perlu mengatasi semua kesulitan yang ada. Hal ini mampu membuat siswa memiliki kemampuan memecahkan masalah menjadi lebih baik dan bermakna. Proses pemecahan masalah sampai menghasilkan sebuah produk inilah yang menjadikan peserta didik merasa tertantang.

\section{Micro-cycle 6 (evaluation and reflection)}

Tahap ini merupakan tahap akhir pembelajaran menggunakan bahan ajar berbasis proyek. Pada tahap ini dilakukan posttest yang digunakan untuk mengukur tingkat efektivitas bahan ajar yang dikembangkan seperti yang terlihat pada tabel 7.

Tabel 7. Ringkasan hasil Posttest berpikir kreatif dan obervasi karakter wirausaha

\begin{tabular}{ccc}
\hline Responden & $\begin{array}{c}\text { Nilai } \\
\text { Posttest }\end{array}$ & $\begin{array}{c}\text { Rerata } \\
\text { Karakter } \\
\text { Wirausaha } \\
(\mathbf{\%})\end{array}$ \\
\hline 1 & 73 & 80 \\
2 & 85 & 88 \\
\hline Rata-Rata & $\mathbf{7 9}$ & $\mathbf{8 4 \%}$ \\
\hline
\end{tabular}

Berdasarkan tabel 7 rata-rata nilai posttest keterampilan berpikir kreatif peserta didik tunanetra adalah 79 sedangkan persentase karakter jiwa wirausaha adalah sebesar $84 \%$. Artinya bahan ajar tematik "jenitri” berbasis proyek efektif digunakan untuk meningkatkan keterampilan berpikir kreatif dan karakter wirausaha peserta didik SMA tunanetra di SLB Putra Manunggal Gombong, Kebumen. Hal ini sejalan dengan penelitian Yuliana, dkk bahwa pembelajaran menggunakan modul berbasis PjBL efektif untuk menumbuhkan kreativitas

\footnotetext{
${ }^{9}$ Suparno P, Metodologi Pembelajaran Fisika: Konstruktivistik Dan Menyenangkan. (Yogyakarta: USD, 2007).

${ }^{10}$ Chiang \& Lee, "The Effect of Project Based Learning on Learning Motivation and Problem Solving Ability of Vocational High School Students," International Journal of Information and Education Technology 6, no. No 9 (2019): 709-12.
} 
peserta didik. ${ }^{11}$ Dilanjutkan oleh Fatimah bahwa pembelajaran proyek mampu meningkatkan keterampilan berpikir kreatif peserta didik. Hal ini dikarenakan pembelajaran berbasis proyek memberikan kesempatan yang lebih besar kepada peserta didik dalam berpikir dan mengeksplor kemampuan atau keterampilan dalam menyelesaikan sebuah tugas dan mencari konsep yang tepat. ${ }^{12}$

Tabel 8. Hasil wawancara Peserta Didik pada Siklus II (Micro-cycle 6)

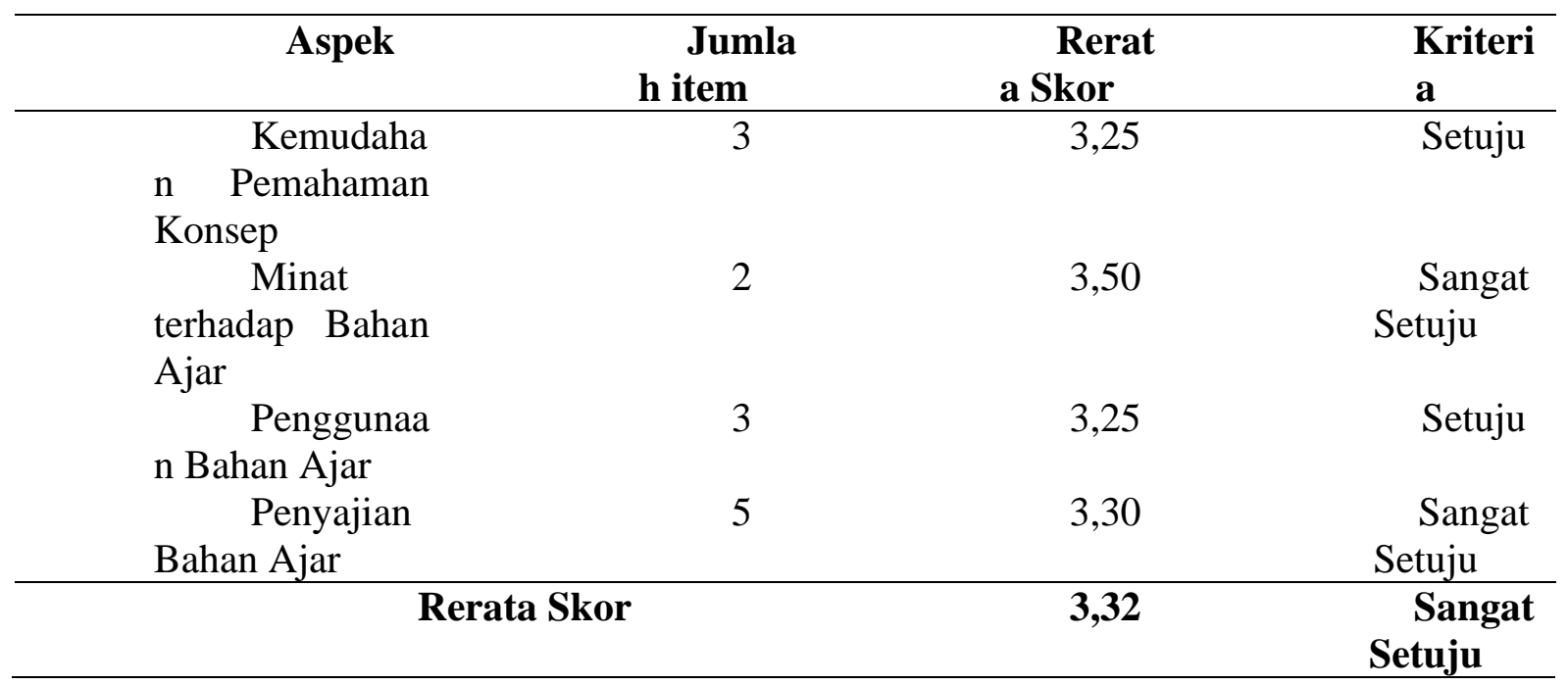

Berdasarkan tabel 8 dapat diketahui bahwa rerata skor respon peserta didik pada siklus II menunjukkan kategori Sangat Setuju. Hal ini menunjukkan bahwa peserta didik sangat antusias dalam menggunakan bahan ajar selama pembelajaran. Berdasarkan hasil wawancara, bahan ajar yang telah direvisi sudah layak digunakan sebagai bahan ajar dalam pembelajaran. Pembelajaran menggunakan bahan ajar berbasis proyek merupakan kegiatan pembelajaran yang memfokuskan pada penyelesaian sebuah produk/karya dari permasalahan yang diberikan oleh pendidik. Oleh sebab itu, kegiatan ini mampu menggali daya berpikir dan kreativitas peserta didik dengan caranya sendiri. Aktivitas proses penyelesaian masalah, pembuatan karya sampai menjualkan produk ke orang lain adalah salah satu rangkaian kegiatan dalam menumbuhkan keterampilan berpikir kreatif peserta didik yaitu menganalisis, mengevaluasi, dan mencipta.

Proses jual beli merupakan salah satu aktivitas yang mampu melatih peserta didik dalam mengembangkan karakter jiwa wirausaha sekaligus memahami konsep jual beli menurut Islam.

\footnotetext{
${ }^{11}$ P.W Yuliana, Prasetyo, Z.K., \& Hastuti, “Pengembangan Modul IPA Berbasis Project Based Learning Untuk Menumbuhkan Kreativitas Peserta Didik Kelas VIII SMP," E- Journal Pendidikan IPA 7, no. No 4 (2018): 121-26. 12 S Fatimah, "The Effect of Project Based Science Learning on PGSD Student's Creative Thinking Ability. Jurnal Pendidikan Indonesia" Vol 7, no. 2 (2018): 100-105.
} 
Hal ini sejalan dengan penelitian Wikanta \& Gayatri bahwa pembelajaran berbasis proyek cukup efektif dalam menanamkan karakter kewirausahaan peserta didik. ${ }^{13}$

Berdasarkan hasil observasi dan wawancara, jiwa wirausaha peserta didik tunanetra di SLB Putra Manunggal Gombong Kebumen selalu dikembangkan selama proses belajar mengajar di sekolah. Hal ini merupakan salah satu program dari sekolah, bahwa peserta didik berkebutuhan khusus diharapkan mampu memilki skill/keterampilan yang nantinya mampu menghasilkan sebuah karya dan manjadikan siswa yang mandiri.

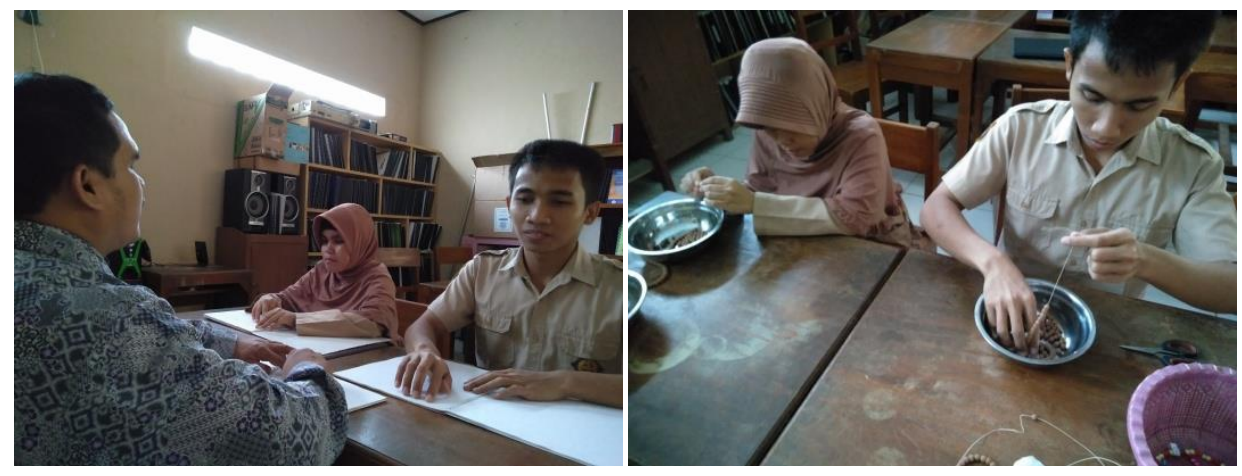

Gambar 9. Pembelajaran berbasis proyek menggunakan bahan ajar tematik "jenitri”

Gambar 9 adalah salah satu kegiatan peserta didik selama pembelajaran menggunakan bahan ajar berbasis proyek. Aktivitas membaca/literasi menjadi fokus utama selama peserta didik menggunakan bahan ajar sebagai salah satu media dalam pembelajaran untuk menjembatani peserta didik membuat sebuah proyek.

\section{KESIMPULAN}

Hasil penelitian menunjukkan bahwa: 1) Bahan ajar tematik “jenitri” berbasis proyek layak digunakan bagi peserta didik tunanetra; 2) Pembelajaran proyek menggunakan bahan ajar tematik efektif meningkatkan keterampilan berpikir kreatif dan mengembangkan karakter wirausaha peserta didik tunanetra; 3) Besar pengembangan karakter wirausaha peserta didik tunanetra menunjukkan kategori tinggi/baik yaitu dengan persentase sebesar $84 \%$, sedangkan peningkatan keterampilan berpikir kreatif peserta didik menunjukkan kategori sedang dengan nilai $N$-Gain 0,60 .

\footnotetext{
${ }^{13}$ Wikanta \& Gayatri, “Pembelajaran Berbasis Proyek Dalam Menanamkan Karakter Kewirausahaan, Keterampilan Proses Sains, Dan Keterampilan Berpikir Tingkat Tinggi," Jurnal Ilmu Pendidikan 23, no. No 2 (2017): 171-75.
} 


\section{DAFTAR PUSTAKA}

Amin. 2016. Analisis Bahan Ajar Modul Statistika Pada Program Studi Pendidkan Matematika IKIP PGRI Bojonegoro. Jurnal Edutama. Vol 3 (2): 1-8.

Arikunto. 2006. Prosedur Penelitian Suatu Pendekatan Praktik. Jakarta: Rineka Cipta. Azwar. 2014. Reliabilitas dan Validitas. Yogyakarta: Pustaka Pelajar.

Chiang \& Lee. 2016. The Effect of Project Based Learning on Learning Motivation and Problem Solving Ability of Vocational High School Students. International Journal of Information and Education Technology Vol 6 (9): 709-712.

Fatimah. 2018. The Effect Of Project-Based Learning On Creative Thinking Skills Toward Preservice Teacher In Primary Teacher Education Program. Jurnal Pendidikan Indonesia $\quad$ list of accepted papers Vol 7 (2).

Hake. 2007. Design-Based Research in Physics Education Research.: NSF Grant DUE. Meltzer. 2002. Journal: The Relationship Between Mathematics Preparation and Conceptual Learning Gain in Physics: A Possible "Hidden Variable" in Diagnostic Pretest Score. Am.J.Phy. 70 (12) Desember. American Association of Physics Teachers. Department of Physics and Astronomy, Lowa State University.

Muhammad. 2018. Pengaruh Metode Pembelajaran Kooperatif Tipe Jigsaw Terhadap Motivasi dan Hasil Belajar Mahasiswa. Jurnal Keperawatan. Vol 9 (1): 65-71.

Pool \& Laubscher. 2016. Design-based reasearch: is this a suitable methodology for short- $\quad$ term projects?. Educational Media International. Vol 53 (1): $42-52$. Sari. 2015. Pengaruh Pembelajaran Berbasis Proyek Terhadap Kreativitas Siswa Melalui Elektroskop Sederhana. Prosiding Seminar Nasional Fisika (EJournal) UNJ. Vol IV: 19-24.

See. 2015. The Effect of Project Based Learning on Level of Content Knowledge of Pre-Vocational Subject. Mediterranean Journal of Social Sciences Vol 6 (6): 369-375. Suhendro. 2018. Pengaruh Metode Demonstrasi dan Metode Ceramah Terhadap Hasil Belajar Geografi di SMAN 3 Metro. FKIP: Unila.

Suparno P. 2007. Metodologi Pembelajaran Fisika: Konstruktivistik dan Menyenangkan. Yogyakarta: USD. 
Triyanto \& Rudiyati. 2017. Pengembangan Modul Pembelajaran Aksara Jawa "Dinta Swara" dalam Huruf Braille untuk Siswa Tunanetra. Jurnal Pembanguna Pendidikan: Fondasi ～dan Aplikasi. Vol 5 (2): 176-186.

Undang-Undang Republik Indonesia Nomor 20 (2003). Sisdiknas dan Peraturan Pemerintah Nomor 47 Tahun 2008 tentang Wajib Belajar. Bandung: Citra Umbara.

Utomo. 2018. Pengembangan Modul Braille Pembelajaran Orientasi dan Mobilitas Tingkat Lanjut untuk Siswa Tunanetra di SMPLB - A YPAB Surabaya. Tugas Akhir: Program Pascasarjana UM.

Warta Ekspor. 2017. Pengembangan Desain Perhiasan Jenitri. Kementerian Perdagangan RI.

Widoyoko. 2012. Teknik Penyusunan Instrumen Penelitian. Yogyakarta: Pustaka Pelajar.

Wikanta \& Gayatri. 2017. Pembelajaran Berbasis Proyek dalam Menanamkan Karakter Kewirausahaan, Keterampilan Proses Sains, dan Keterampilan Berpikir Tingkat Tinggi. Jurnal Ilmu Pendidikan. Jilid 23 (2): 171-175.

Yamasari. 2010. Pengembangan Media Pembelajaran Matematika Berbasis ICT yang Berkualitas. Makalah disajikan pada Seminar Nasional Pascasarjana XITS, Surabaya.

Yuliana, Prasetyo, Z.K., \& Hastuti, P.W. 2018. Pengembangan Modul IPA Berbasis Project based Learning untuk Menumbuhkan Kreativitas Peserta Didik Kelas VIII SMP. E-Journal Pendidikan IPA. Vol 7 (4): 121-126. 